\title{
Effectiveness, Efficiency and Instruction Appeal of Blended Learning Model
}

\author{
https://doi.org/10.3991/ijoe.v16i04.13389 \\ Wasis Djoko Dwiyogo ${ }^{(凶)}$, Carolina Ligya Radjah \\ Universitas Negeri Malang, Malang, Indonesia \\ wasis.djoko.fik@um.ac.id
}

\begin{abstract}
The practice of learning, to acquire success, has so far been measured by the level of effectiveness with a percentage range from $0 \%$ to $100 \%$ and converted into values $\mathrm{E}$ to $\mathrm{A}$. While in the science of knowledge, learning outcome is measured by effectiveness, efficiency, and attractiveness. Dwiyogo's research [1][2] and 2015 developed a tuition design model that combines face-to-face schooling using offline resources(print, audio, video, computer) and online knowledge training (internet and smart phones) known as Blended Learning-Based Instruction Design Models. Numerous studies have been conducted to test the potency, capability, and fascination of learning. However, the objectives of this study with respect to Dwiyogo's model are:(1) Examining experts on its usage, (2) Applying the model in courses, and (3) Testing the productivity, and capability. This research makes use of the survey and quasi-experimental design methods. The data consists of a total of 3 experts, 113 students, and 6 teachers with result showing that the blended learning model using eight items produced huge output $(=4.750, \mathrm{SD}=0.361)$. Based on the components of the expert test, it can be concluded that the learning model developed is appropriate and can be implemented. Student opinion with respect to this model showed a high level of agreement $(=3.415, \mathrm{SD}=0.536)$. This shows that students who applied blended learning based instruction models responded positively to its implementation. Therefore, this technique can enhance knowledge thereby, making the act of efficient, effective, and instruction appeal.
\end{abstract}

Keywords - Blended Learning Based Learning, Effective, Efficient, and Instruction Appeal.

\section{Introduction}

The purpose of learning is to improve and develop knowledge and in order to do this, it should be selected, established and developed an optimum education acquisition technique to achieve desired outcome [3].Reigeluth [4] defined learning design as a process used to determine the most appropriate methodology that effectively works to enable learners experience change of knowledge and skills towards the right direction. Reigeluth use the term "blue print" for the model to be developed which is in the same process as an architect building. 
In order to develop the right knowledge acquisition model, proper analysis should be carried out on future schooling trends with respect to learning strategy and content. There is a tendency that the current education teaching technique has shifted from traditional to modern, also known as the era of knowledge, where students learn from any location (classroom, library or at home), irrespective of the time, and from any professional i.e. lecturers, experts, practitioners or the society using various sources, for example the internet, CDs, radio, television, laboratory. The educational technique which combines various academic sources and modes is called blended learning from the word "blended" which means combination or mixture and "learning" which means to learn or study. However, it literally refers to the educational activity that combines face-to-face schooling technique and computer-based model (online and offline). Thorne [5] describes this model as an opportunity to integrate the innovative and technological advances offered by online acquisition with the interaction and participation offered in traditional learning. In addition, Bersin [6] defines it as:

"...The combination of different training "media" (technologies, activities, and types of events) to create an optimum instruction program for a specific audience. The term "blended" means that traditional instructor-led training is being supplemented with other electronic formats. In the context of this book, blended learning programs use many different forms of e-learning, complemented with other live formats"

The study on the contributions of blended-learning components show that the most contributing technique are assignments (mean score $=4.72$ ), textbooks (mean score $=4.54$ ), face-to-face presentation (mean score $=4.42$ ) and face-to-face lecture with instructors (mean score $=4.15$ ). Online video also contributed towards learning (mean score $=3.83$ ) while online textbook gives average contribution (mean score $=3.32$ ). Despite the fact both afforded a low percentage of $46.5 \%$, the learners occasionally make use of video and online textbooks. In higher institutions, this educational technique comprises of once-a-week face-to-face lecture with students utilizing online learning for projects or other assignments [7].Some of the advantages of using the blended learning strategy are

a) To achieve knowledge acquisition purpose,

b) To change the pattern of schooling from teacher to student-centered,

c) To balance learner's education independence and to motivate students [8][9][10] Dziuban et al.[11].

This academic technique is utilized for the following reasons

1. To enrich knowledge management

2. To facilitate access to educational tools

3. To improve learning interaction

4. Personal agency

5. Cost effectiveness

6. To ease revisions [9]

Initially, the type of learning adopted by most of education institutions in Indonesia is teacher-centered where the lecturer is the major source of knowledge. However, the 
inception of printing devices, lead to the use of textbooks. Furthermore, the development of audio and audio-visual technology, along with the computer, internet and mobile phones (smartphone) in the 21st century enables the easy and flexible acquisition of skills through these gadgets. Unfortunately, most teachers in various educational backgrounds are yet to acquaint themselves with the use of textbooks and various online sources. In order to develop knowledge skills using various technological learning sources, a sensitive model that combines both traditional and modern educational techniques called blended-learning-based model should be developed. This prototype combines three major learning sources, namely face-to-face, offline and online.

The findings of Dwiyogo's studies [1],[2] showed that the most current educational trends consists of face-to-face, offline (computer interactive) and online (internet) knowledge techniques. The traditional, face-to-face strategy has recently shifted towards offline and online learning. Online learning, therefore, combines face-to-face meeting, with teacher's ability to manage academics should be directed towards blended learning. Based on the data from the respondents, $11 \%$ understood the concept associated with the new model, $41 \%$ are yet to get acquainted, while $48 \%$ have become familiar with the tool. With regards to its development need in solving academics problems, $97 \%$ were of the opinion that it assisted in solving academic difficulties. The remaining 3\% disagrees with this as they stated that there is no need in adapting to the new model since they will retire in a short time. Limited school facility is another reason for the disagreement. However, the hesitation to use technology as an integral part of learning can be traced to the need for academicians to make use of current technological trends.

The need analysis blended with the developed knowledge acquisition theories. The model is flexible and enables developers to make adjustments. This is illustrated in Fig. 1.

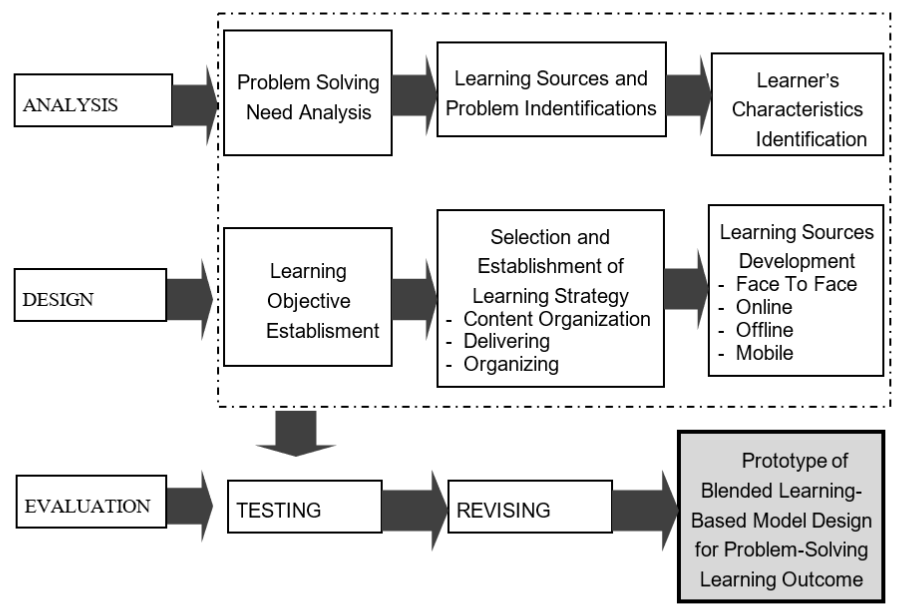

Fig. 1. Blended-Learning-Based Model Design for Problem-Solving Learning Outcome [2] 
In general, the model development is conducted in three stages, namely:

1. Analysis

2. Design

3. Evaluation

\section{Analysis}

This is the first stage which consists of

1. Problem-solving

2. Learning source and problems identification

3. Characteristics identification

\subsection{Problem-solving need analysis}

In this stage, the researcher conducts the following activities i.e.

1. Analyzes the current condition

2. Identify some aspects to master (knowledge, attitude and skills)

3. Identify differences between the purpose, current and expected conditions

4. Decide and take notes on some advantages related to the performance

5. Deciding the priorities to overcome the current problems.

The data collection methods in this stage are phone calls, direct interviews, emails, questionnaires, videos as well as observations.

\subsection{Learning sources and problems identification}

This stage analyzes information from particular parties and media. It involves

1. Identifying teachers as learning source which includes their capabilities to develop online, offline and mobile learning sources

2. Identifying learning sources i.e. Textbooks, audio, audio-visual, computer, the internet, smart phone/ tablet at the schools

3. Identifying web and other learning sources.

The aspect being analyzed is dependent on the availability of technology in the academic environment. Other findings show how close the learners are with the technology and to what extent it is utilized. Some aspects to be taken into consideration are the types of available technology to use as references. The research analyses are used to decide the appropriate solving problems in learning process and the right skill to be possessed by the teacher. 


\subsection{Learner's characteristics identification}

In this stage, the researcher conducts an analysis on the learner's initial capabilities and characteristics which is pivotal in deciding the academic starting point. Data on the population characteristics were used which comprises of learner's age, stage, interest, occupation, health, learning motivation, achievement, initial capability, capabilities in literacy, socio-economic status and/or foreign language mastery. In addition, it is important to determine some information on the learner's attitude towards the materials to be studied.

\section{Design}

The second development stage is the design phase which consists of:

1. Learning purpose

2. Selection strategy

3. Source development

\subsection{Learning purpose}

The purpose of this stage is to identify and organize previous educational steps based on their level of importance. These include cognitive, affective, and psychomotor strands (based on The Bloom's Taxonomy) or verbal information, intellectual capability, cognitive strategy, attitude and psychomotor (The Gagne's Taxonomy).

\subsection{Selection strategy}

Organizing the content means elaborating the steps required to achieve the knowledge. Learning analysis is carried out using component of variables comprising of two functions namely

1. To deliver educational content to students,

2. To provide the right information/materials to capture learners' capabilities through assignment and test.

The delivery strategy involves physical contact, teachers/lecturers, educational materials and other academic activities. In other words, media is one of the essential components used in the learning process.

The management process includes

1. Scheduling

2. Notetaking

3. Managing learner's motivation

4. Guidance 


\subsection{Learning source development}

The source of learning that facilitates learners are face-to-face, online and offline techniques. The activity carried out in the stage is selecting the most appropriate source or materials that match the availability of the technology in a educational environment. The bases of the analysis are availability and accessibility to technological tools. The result of the analysis is to decide the most suitable media to develop with the development carried out in four stages. The first is making storyboard or describing process for delivering learning materials into images to enable everyone have a clear idea of the programs being developed. This involves formulating both visual images and audio recording into well-organized manner in line with learning stages. The second is the production stage which involves every element of the program and combines all into one unified device. The third is the testing and reviewing stage which involves editorial, functional and technical examination. The goal is to evaluate some errors inherent the program and to ensure the revisions were correctly conducted. The final stage implements the media into learning activities using software capable of producing the multimedia. VideoMakerFX is used to create the user interface, with animations created for each icon. AutoPlay Studio version 8 is the software used to create the overall outlook of the interactive multimedia, while video-recording is carried out using desktop-based outlook with the help of ScreenCastOMatic. Finally, the Ncesoft Flipbook Maker is used for the e-book outlook.

\section{Evaluation}

In the evaluation stage, the following activities are to be carried out:

1. Testing

2. Revising

3. Producing a prototype of the model

\subsection{Testing}

The evaluation carried out is formative using the revision purpose. In the study, the formative evaluations are in the form of experts' reviews, individual, small-group and field tests.

\subsection{Revising}

Based on the reviews from experts, individual, small-group and field tests, the researcher gained some feedbacks used to enhance the proposed model.

To determine the blended learning model usage in learning, three experts in the media, learning, and technology fields were involved. The instrument used is the questionnaire using a Likert scale with $5=$ strongly agree, $4=$ agree, $3=$ quite agree, $2=$ disagree, and $1=$ disagree. Based on the expert test, data were obtained which 
generally stated that the model could be implemented with a high level of agreement. This is illustrated in Table 1.

Table 1. The Results of the Experts' Evaluation toward Blended-Learning-Based Model Design for Problem-Solving Learning Outcome

\begin{tabular}{|c|l|c|c|}
\hline No & \multicolumn{1}{|c|}{ Variables/ Main Statement } & Mean & SD \\
\hline 1 & Content organization & 5.000 & 0.000 \\
\hline 2 & Compatibility of components & 4.667 & 0.577 \\
\hline 3 & Clarity of stages & 5.000 & 0.000 \\
\hline 4 & Model effectiveness & 5.000 & 0.000 \\
\hline 5 & Efficiency of the model & 4.667 & 0.577 \\
\hline 6 & Model flexibility & 5.000 & 0.000 \\
\hline 7 & Ease of implementation & 4.333 & 0.577 \\
\hline 8 & Benefit & 4.667 & 0.577 \\
\hline & Total & 4.750 & 0.361 \\
\hline
\end{tabular}

Based on Table 1, the data shows that the highest score is in items number 1, 3, 4, and $6(=5,000, \mathrm{SD}=0,000)$ while the lowest average is in the variable related to implementation $(=4,333, \mathrm{SD}=0,000)$. Overall the results of expert tests on eight items showed high results $(=4.750, \mathrm{SD}=0.361)$. Based on the components of the expert test, it can be concluded that the learning model developed is appropriate and can be implemented at a later stage.

This is a development research conducted from 2014-2016. It is based on needs analysis, learning theories, and outcomes. Data analysis used is the descriptive statistics which reviews data related to averages and standard deviations.

\section{$5 \quad$ Learning Outcomes}

Learning outcomes are defined as effects used as indicators under different conditions. This effect can be an intentionally designed and can also be a real using certain learning methods. If the reference is desired, then this result must be set before developing the educational technique. Therefore, the chosen method is the optimal strategy used to achieve earlier set results. This can be classified into three, namely

1. Effectiveness

2. Efficiency

3. Attractiveness

\subsection{Learning effectiveness.}

Measurement of learning effectiveness must always be associated with the set objectives. Seven indicators can be used to determine the effectiveness of learning, namely:

1. Accuracy of mastery behavior

2. Speed of performance 
3. Conformity with procedures

4. Quantity of performance

5. Quality of final results

6. The level of transfer

7. The level of retention

\subsection{Learning efficiency}

Learning efficiency is measured by the ratio between effectiveness and the amount of time students use or the amount of learning costs or resources used. Thus there are 3 indicators used to determine the level of efficiency, namely:

1. Time

2. Personnel

3. Resources

What is the amount of time needed by students to achieve the set goals? How many personnel are involved in the implementation process? What is the use of the educational resources? The answers to these questions will provide an overview of the level of efficiency inherent the program.

\subsection{Attractiveness}

Learning attractiveness is measured by observing the ability of students understanding the model. However, in its delivery, will largely depend on the quality of the academic tool. To describe its attractiveness pressure is placed on the quality of the field of study.

Basically, each field of study has its own charm, although this attraction is very dependent on the characteristics of students, such as: talents, needs, interests, and trends or other individual choices. A field of study is highly attractive because it can be in accordance with the talents of students or required owing to interest. This made learners study the model, however it is influenced by its organization procedure and delivered. The quality of knowledge is always related to learning methods which are optimal for achieving academic goals, under certain conditions. This means that in order to obtain high educational knowledge, the study field of study must be arranged with the right organizational and delivery strategy. Furthermore, Important variables used to attract students are in the form of rewards. The starting point comprises of organizing strategy, delivery, and learning management. This is explained by three variables as stated by Degeng [3] and illustrated in diagram 2. 




Fig. 2. Learning Variables

Learning outcomes is a combination of various academic methods measured by its effectiveness. The difference in each technique, lie on its level of efficiency and attractiveness.

\section{$6 \quad$ Research Design}

This study uses two types of researches. The first was conducted from 2015-2018 using data collected from teaching students during the second semester of postgraduate sports education, State University of Malang.

Subsequent research obtained data by implementing the blended learning model on the learning outcomes for effectiveness, efficiency, and learning attractiveness. In this study therefore, four students were involved as executors from 2018-2019. Data was collected through documentation studies, observations, questionnaires, and semistructured interviews.

\section{$7 \quad$ Participants}

The survey subjects were all 113 post graduate students (S2) in Sports Education in State University of Malang who participated from 2015 to 2018. The survey provided data related to the application of the blended-based learning.

\section{Data Analysis}

Data analysis conducted on this survey research makes use of descriptive examination in the form of percentages and triangulations. The questionnaire in this study has 
fulfilled the reliability requirements indicated by Cronbach's $\alpha$ which is 0.902 . Data collected through questionnaires was obtained through interviews, observations, and documentation.

\section{$9 \quad$ Result}

The first phase of this study aims to analyze the developed blended learning model. This stage contains survey conducted on 113 postgraduate students of the Sports Education study program class of 2014 to 2018

The survey results showed that students agreed with all the listed items as illustrated in Table 2. Some respondents who disagreed (score 2) appeared on the item cost efficiency $(=3.468, \mathrm{SD}=0.608)$, clarity description $(=3,400, \mathrm{SD}=0.581)$, ease of implementation $((=3.243, \mathrm{SD}=0.553)$, and increase motivation $(=3.327, \mathrm{SD}=$ $0.537)$.

Table 2. The Results of the Students' Opinions toward Blended-Learning-Based Model

\begin{tabular}{|c|l|c|c|c|c|c|}
\hline No & Variables/ Main Statement & $\mathbf{N}$ & Min & Max & Mean & SD \\
\hline 1 & Effective & 113 & 3.00 & 4.00 & 3.500 & 0.504 \\
\hline 2 & Interactive & 113 & 3.00 & 4.00 & 3.467 & 0.503 \\
\hline 3 & Flexible & 113 & 3.00 & 4.00 & 3.450 & 0.502 \\
\hline 4 & Time efficiency & 113 & 3.00 & 4.00 & 3.467 & 0.503 \\
\hline 5 & Cost efficiency & 113 & 2.00 & 4.00 & 3.468 & 0.608 \\
\hline 6 & Clear description & 113 & 2.00 & 4.00 & 3.400 & 0.581 \\
\hline 7 & Easy to implement & 113 & 2.00 & 4.00 & 3.243 & 0.553 \\
\hline 8 & Increase motivation & 113 & 2.00 & 4.00 & 3.327 & 0.537 \\
\hline & Total & & & 3.415 & 0.536 \\
\hline
\end{tabular}

Based on the Table 2, it can be concluded that student opinion with respect to the model was high with all items averaging $(=3.415, \mathrm{SD}=0.536)$. This shows that overall, learners gave a positive response to its implementation.

In connection with follow-up survey data, students are advised to master how to utilize the software. Data from the survey on self-assessment is presented in Table 3. PowerPoint is the program with the most proficiency level (53\%). The software with the least proficiency level is AutoPlay and Sigil (15\%)

Table 3. Results of the Survey on Self-Assessment of Self-Ability

\begin{tabular}{|l|c|c|c|c|c|c|}
\hline \multirow{2}{*}{\multicolumn{1}{c|}{ Software }} & \multicolumn{2}{c|}{ Mahir } & \multicolumn{2}{c|}{ Bisa } & \multicolumn{2}{c|}{ Tidak Bisa } \\
\cline { 2 - 7 } & $\boldsymbol{n}$ & $\boldsymbol{\%}$ & $\boldsymbol{N}$ & $\boldsymbol{\%}$ & $\boldsymbol{n}$ & $\boldsymbol{\%}$ \\
\hline Word & 60 & 45 & 53 & 55 & 0 & 0 \\
\hline PPT & 65 & 53 & 48 & 47 & 0 & 0 \\
\hline Flipbook & 60 & 28 & 63 & 72 & 0 & 0 \\
\hline ScreenCastO'Matic & 44 & 18 & 69 & 82 & 0 & 0 \\
\hline AutoPlay & 42 & 15 & 71 & 85 & 0 & 0 \\
\hline Mind Manager & 43 & 17 & 570 & 83 & 0 & 0 \\
\hline Sigil & 42 & 15 & 71 & 85 & 0 & 0 \\
\hline
\end{tabular}


In addition to survey, a case study was conducted to provide information with respect to its implementation. Through this research, students conduct learning designs using developed models, then observed its outcomes, including the level of effectiveness, efficiency, and attractiveness. Students who carried out the thesis using Dwiyogo Model [2], were Kristiono [12], [13], Setiawam [14], Samiun [15], and Gusdiyanto [16]. The six undergraduates are postgraduate sports education students at the State University of Malang. The study conducted is a type of research and development ( $R$ \& D) using the model developed by Dwiyogo [2].

The purpose of Kristiono's research is to produce a blended learning product (faceto-face, offline, and online) in sports nutrition science subjects, and to test its productivity, and capability. This study makes use of a conceptual model in line with model developed by Dwiyogo [2]. The design steps are:

1. Problem solving needs analysis

2. Identifying learning resources and constraints

3. Recognizing trainee characteristics

4. Setting objectives

5. Selecting

6. Evaluating strategies

While the evaluation phase comprises of:

1. Trial

2. Revision

3. Learning prototype based on the model.

Steps 1 to 3 is the analysis phase, 4 through 6 are the design stage, while stages 7 through 9 are evaluations phases.

The results are to create products for learning sports nutrition-based courses. The components include:

1. Face-to-face methods using printed books,

2. Offline strategies using the studio auto play 8.5 application containing material, photos and videos,

3. Online learning methods by utilizing the Edmodo virtual class to share material and evaluate online quizzes.

The courses presented include sports physiology, sports nutrition, nutrition for health and fitness, supplements and doping, malnutrition, nutrition in sports, water and electrolytes, and management of eating athletes. This product is accessible to teachers and students irrespective of their destination. The results on effectiveness tests obtained by researchers from 3 meetings differed.

During the first meeting, the following were obtained:

1. The lowest value of 50 letters $D$

2. The highest value of 100 letters $A$

3. The value of 100 letters A $(2.85 \%)$ 
4. The value of 90 letters $\mathrm{A}(14.8 \%)$

5. The value of 80 letters A $(31.42 \%)$

6. Value of 70 letters B $(34.28 \%)$

7. The value of 60 letters $C(14.28 \%)$

8. Value of 50 letters D $(2.85 \%)$

The overall average value of the student class at the first meeting is obtained the value of letter B $(74.85 \%)$

In the second meeting, is the following was obtained:

1. The lowest value of 70 letters $B$

2. The highest value of 100 letters $A$

3. The value of 100 letters A $(8.57 \%)$

4. The value of 90 letters A (37.14\%)

5. The value of 80 letters A $(37.14 \%)$

6 . The value of 70 letters B (14.28\%)and

7. The overall average value of the student class at the second meeting is the value of letter A $(84 \%)$

Finally the following was obtained in the third meeting:

1. The lowest value of 80 letters $A$

2. The highest value of 100 letters $A$

3. The value of 100 letters A $(5.71 \%)$

4. The value of 90 letters A $(40 \%)$

5. The value of 80 letters A $(45.71 \%)$

6 . The overall average value of the student class at the second meeting is the value of letter A $(85.14 \%)$

The results of the Efficiency test at the first meeting are as follows:

1. The longest total time 67 minutes 54 seconds and the fastest time 67 minutes 1 second;

2. In the second meeting the total time to study and work on the questions was 73 minutes 9 seconds and the fastest was 55 minutes 9 seconds, and

3. In the third meeting the total time of study and work was 70 minutes for the longest time and 57 minutes 30 seconds for the shortest.

Face-to-face attraction, obtained:

1. Very interesting 300 points $(71.42 \%)$

2. Attractive 90 points $(21.42 \%)$.

Offline attraction was:

1. Very interesting 372 points $(66.42 \%)$

2. Attractive 135 points $(23.57 \%)$

Online attractiveness obtained was: 
1. Very interesting 176 points $(62.85 \%)$

2. Attractive 165 (58.92\%)

For the overall results of individual points:

The highest points was 36; and the lowest 29. The amount obtained is 1159 points with a maximum number of 1260 points. The average of all data obtained gets very valid percentage $(91.98 \%)$ criteria.

The model increased efficiency of the previous 16 meetings, within a relatively short time. The research was conducted with the aim of developing Adaptive physical education textbook that uses blended learning model for students of the Faculty of Sport Science, State University of Malang. The model developed by Dwiyogo [2] was used in this study.

The results of this study produced three teaching materials products, namely:

1. Face-to-face learning,

2. Interactive multimedia in the form of auto play for offline knowledge

3. Edmodo for online skill acquisition.

The application of blended learning based adaptive physical education teaching materials is able to improve student learning outcomes which include effectiveness, efficiency, and attractiveness and are tested on 70 samples. The components obtained are:

1. The first meeting in chapters 2 and 3 comprises of face-to-face components with an average score of $87.43 \%$ with the final value A and the average length of reading and working on sola 1.00.40 1 hour 40 minutes,

2. The second meeting in chapters 4 and 5 of the offline component had an average score of $89.50 \%$ with the final value $\mathrm{A}$ and an average reading length of 0.59 .45 (fifty nine minutes forty-five seconds), and

3. The third meeting in chapters 6 and 7 of the online component with an average score of $92.36 \%$ while the final value A had an average reading and working length of 0.58 .15 (58 minutes 15 seconds).

For the attractiveness component, the percentage of attractiveness of blended learning-based adaptive physical education teaching material was obtained by $94 \%$ with very valid criteria.

The various product suggestions during broader dissemination need to be evaluated to obtain data conformity on environmental conditions. Similar research is expected to assess the psychomotor. Masgumelar [13] conducted a research with the aim of:

1. Developing game modification products in physical education, sports, and health

2. Testing the effectiveness of these products. Dwiyogo [2] blended learning development model was utilized with data obtained from 80 senior high school students and 4 experts.

The results of the research and development include product development using the blended learning model for high school students (SMA) which consists of: 
1. Printed books equipped with a QR code for face-to-face education

2. Interactive multimedia for offline knowledge acquisition, and edmodo for online learning.

The results of the study on product trials were given to 80 subjects, with the following results:

1. $90.97 \%$ small group trials

2. $91.18 \%$ large group trials

The results of the effectiveness test obtained an average of all the meetings with the lowest score (B) while 5 students had A grades. Overall, the achievement of the average learning outcomes is 90.73 with credit A. Efficiency test to read the material and work on the first meeting questions, produced an average time of 1:08:32 1 hour 80 minutes 32 seconds, the second produced an average time of 1:06:04 or 1 hour 6 minutes 4 seconds, while the third produced an average time of 1:04:56 or 1 hour 4 minutes 56 seconds. When compared with the learning time of $2 \times 50$ minutes or 1 hour and 40 minutes, efficiency is achieved.

Attractiveness test results:

1. Face to face meeting had an average of $92.88 \%$ which was very interesting,

2. The second meeting (offline) had an average of $93.48 \%$

3. Meeting III (online) had an average of $93.69 \%$

Suggestions from this study are:

1. Before developing the product attention should be paid to the material that needs to be tested

2. Research and development using the blended learning approach should be able to pay more attention to the conditions,

3. In the test further effectiveness should use a comparison group, therefore the products manufactured can be more meaningful in improving learning outcomes.

The study was conducted by Samiun [15] with the aim of developing a blended learning based athletic media for Physical Health Education students and Recreation in IKIP Budi Utomo Malang. The method used in this study refers to Dwiyogo's blended learning development model [2].Before conducting field tests, product trials were carried out on.

1. Trial design

2. Product expert evaluation

3. Product plan revision

4. Small group trials of 20 students

5. Product revisions

6. Large group trials of 40 students

7. Final product revision

8. Effectiveness test 
Developing a blended learning model based on athletic learning media health and physical education students in IKIP Budi Utomo Malang, consists of face to face (print media), offline (auto play) and online (edmodo). The results of the learning effectiveness test with an average value of 90.68 in the category of "very complete", is reduced by the average value used by students in a meeting. It can be concluded that in the first meeting lecturer's time was $01.30 .00-0.51 .15$ with an efficiency of 00.38.51, (38 minutes 5 first 1 second), the second it was 01.30.00-0.40.30, with an efficiency of 00.49 .30 , (49 minutes 30 seconds), thirdly the lecturer's time was 01.30.00-0.31.50 get time efficiency 00.58.10, (five first eight minutes ten seconds) while the final meeting time was 01:30. 00-0.24.29with an efficiency of 00.36.01 (36 minutes 1 second). It was a concluded that time efficiency occurs in athletic subjects.

The test results of the development of learning product development obtained the average percentage results:

1. $94.58 \%$ meeting I (face to face)

2. $94.52 \%$ meeting II (offline)

3. $90.5 \%$ meeting III (online) with very interesting criteria.

The results of the small group trials obtained an average percentage of 93.33 including very feasible categories. The results of a large group trial obtained an average percentage of 93.22 including very feasible categories. Furthermore, it can be concluded that blended learning-based on athletic subject products are suitable. The last research was conducted by Gusdiyanto [16] with the of producing a learning product based on blended learning (face-to-face, offline, and online) in sports nutrition science subjects, as well as testing the effectiveness, efficiency, and attractiveness of development products produced in learning outcomes. The method in this research uses a conceptual model that refers to the development of a blended learning based design model [2]. The research subjects were 50 physical and health education students and 3 validation experts including learning experts, material experts and media experts.

The results of sports social anthropology courses produce the following product specifications:

1. Face-to-face method using printed books as learning resources,

2. Offline learning methods using media studio auto play 8.0 application containing material, photos, and videos to support clarity on the material,

3. Online learning methods by utilizing the Edmodo virtual class which can be used to share material and evaluation/online quizzes.

The material presented includes basic concept sociology and sports anthropology, social process and interactions, leadership, aberration and aggression, political relations, mass media relations, economy relations $\mathrm{s}$, and gender issue in sports. This product is arranged for teachers and students who can be accessed anywhere and anytime.

The results obtained from the effectiveness test conducted by researchers from 3 meetings with 35 research subjects are as follows: In the first meeting using the face- 
to-face method with the material in chapters 2, 3 and 4, the average value obtained are:

1. Lowest at 70 with credit B

2. Highest at 100 with credit A

3. Overall value and average of 82.38 credit A.

The second meeting used the offline method through interactive multimedia auto play with the material in chapters 5,6 , and 7 with the following average values:

1. The lowest at $70 \mathrm{~B}$ credits,

2. The highest at 100 credits with $\mathrm{A}$, and

3. An overall average of 83.90 credits A-.

The third meeting using online methods with the material in chapters 8 and 9 obtained an average value.

1. The lowest at $75 \mathrm{~B}+$ credits,

2. The highest at 100 credit $\mathrm{A}$, and

3. Overall and average of 85 credits $\mathrm{A}$ in the "very complete" category.

The efficiency test results obtained from the total time used by students are as follows: The first meeting using face-to-face method with the average time in chapters 2 , 3 and 4 obtained an average time of 01.09 .47 or 1 hour 9 minutes 47 seconds when compared with the time used by lecturers ( $2 \times 50$ minutes) with a time efficiency is 00:30:13 or 30 minutes 13 seconds. The second meeting using offline methods with the material in chapters 5, 6 and 7 obtained an average time of 1:04:39 or 1 hour 4 minutes 39 seconds when compared with the time used by lecturer lecturers $(2 \times 50$ minutes) with an efficiency timeframe of 00:35:21 or 35 minutes and 21 seconds. The third meeting through an online method with an average time of 00:56:37 56 minutes 37 seconds when compared with the time used by lecturers $(2 \times 50$ minutes) with $t$ a time efficiency of 00:43:24 or 43 minutes 24 seconds. It can be concluded that there is time efficiency when using the blended learning method. The test results of the development of learning product development obtained the average percentage results, (1) 92.29\% meeting I (face to face), (2) 93.14\% meeting II (offline), (3) 94.43\% meeting III (online). The overall average test of product attractiveness was $93.29 \%$ with very interesting criteria.

From the research and development results carried out, it can be concluded that the product developed for sports social anthropology is feasible and can be used by teachers and students. It is currently used in the Department of Physical and Health Education, State University of Malang.

\section{Conclusion}

In this conclusion, the overall results of expert tests on the blended learning model from eight items were high $(=4.750, \mathrm{SD}=0.361)$. Based on these components, it can 
be concluded that the model developed is appropriate and can be implemented at a later stage. Student opinion with respect to this prototype showed a high level of agreement on all items $(=3.415, \mathrm{SD}=0.536)$. This illustrates that a good number of learners have applied this model effectively.

\section{References}

[1] W. D. Dwiyogo, "Analisis kebutuhan Pengembangan Model Rancangan Pembelajaran Berbasis Blended Learning (PBBL) untuk Meningkatkan Hasil Belajar Pemecahan Masalah.," Malang Bur. Res. community Serv. State Univ. Malang., 2013.

[2] W. D. Dwiyogo, "Pengembangan Model Rancangan Pembelajaran Berbasis Blended Learning (PBBL) untuk Meningkatkan Hasil Belajar Pemecahan Masalah.," Malang Bur. Res. community Serv. State Univ. Malang., 2014.

[3] I. N. S. Degeng, "Landasan Teoritik Disain Pembelajaran.," Malang Grad. Program. Inst. Educ. Teach. Train. Malang., 1991.

[4] C. M. Reigeluth, "Instructional-design Theories and Models: An Overview of Their Current Status.," Hillsdale, New Jersey Lawrence Erlbaum Assoc. Publ., 1983.

[5] K. Thorne, "Blended Learning: How to integrate online \& traditional learning.," London Kagan Page Limited., 2003.

[6] J. Bersin, "The Blended Bearning Book: Best Practices, Proven Methodologies, and Lessons Learned.," San Fr. Pfeiffer, 2004.

[7] E. Molenda, M., \& Boling, "Creating. In A. Januszewski \& M. Molenda (Eds.), Educational technology: A definition with commentary.," New York Routledge., pp. 82130, 2008. https://doi.org/10.4324/9780203054000

[8] P. Murphy, "The Hybrid Strategy: Blending Face-to-Face with Virtual Instruction to Improve LargeLecture Courses," 2003.

[9] R. Voos, "Blended Learning: What is It and Where Might It Take Us? Sloan-C View," vol. 2, no. 1, pp. 2-5, 2003.

[10] C. Dziuban, J. L. Hartman, and P. D. Moskal., "Blended Learning. Research Bulletin.," 2004.

[11] I. D. Kristiono, "Pengembangan Pembelajaran Berbasis Blended Learning Mata Kuliah Ilmu Gizi Olahraga Untuk Mahasiswa Pendidikan Jasmani, Kesehatan dan Rekreasi.," Tesis. Jur. Pendidik. Olahraga, Pascasarj. Univ. Negeri Malang., 2018. https://doi.org/10.33503/jpjok.v2i1.180

[12] N. K. MasGumelar, "Pengembangan Modifikasi Permainan pada Pembelajaran Pendidikan Jasmani dan Olahraga dan Kesehatan (PJOK) menggunakan Blended Learning untuk Siswa Sekolah Menengah. Tesis tidak diterbitkan.," Malang Pascasarj. Univ. Negeri Malang., 2019 https://doi.org/10.5614/jskk.2018.3.1.2

[13] W. . Setiawam, "Pengmembangan Pembelajaran Karate Berbasis Blended Learning Mahasiswa Pendidikan Profesi Guru Pendidikan Jasmani dan Kesehatan.," Tesis tidak diterbitkan. Malang Pascasarj. Univ. Negeri Malang., 2019. https://doi.org/10.179 77/um040v2i1p62-66

[14] K. Samiun, "Pengmbangan Media Pembelajaran Mata Kuliah Atletik Berbasis Blended Learning di IKIP Budi Utomo Malang.," Tesis tidak diterbitkan. Malang Pascasarj. Univ. Negeri Malang., 2019. https://doi.org/10.30734/jpe.v6i2.568

[15] H. Gusdiyanto, "Development of Blended Learning in Sport Social Antropology for Physical Education and Health Students. Thesis.," Dep. Sport Educ. Grad. Progr. State Univ. Malang., 2019. 


\section{Authors}

Wasis Djoko Dwiyogo is affiliated with the Universitas Negeri Malang. Author area of interest is eLearning and developing.For contact email at, wasis.djoko.fik@um.ac.id

Carolina Ligya Radjah is affiliated with the Universitas Negeri Malang. Author is interested to learning online in blended model.

Article submitted 2020-01-24. Resubmitted 2020-02-15. Final acceptance 2020-02-17. Final version published as submitted by the authors. 